\title{
RANCANG BANGUN SISTEM PENILAIAN KINERJA GURU DAN TENAGA KEPENDIDIKAN BERBASIS KPI UNTUK MENINGKATKAN PELAYANAN SEKOLAH
}

\author{
Arief Saptono*1, Siti Hajar $^{2}$, Citha Pardiani Atmaja Putri ${ }^{3}$ \\ ${ }^{1,2,3}$ Program Studi Sistem Informasi Universitas Raharja \\ Email : *11 arief.saptono@ raharja.info, ${ }^{2}$ hajar@ raharja.info, ${ }^{3}$ citha@ raharja.info
}

\begin{abstract}
Abstrak
Proses penilaian kinerja guru dan tenaga kependidikan di beberapa sekolah masih dijalankan secara manual, dimana perhitungan kinerja hanya dilihat berdasarkan absensi dan masih sangat subyektif, hal ini cukup memakan waktu dalam perhitungan sehingga tidak efektif dan efisien selain itu hasil kurang akurat. Untuk mengatasi permasalahan di atas, dibutuhkan suatu sistem yang terkomputerisasi sehing a bisa mengatasi permasalahan dan mempercepat proses. Oleh karena itu, penelitian ini mengusulkan rancangan sistem penilaian kinerja guru dan tenaga kependidikansecara otomatis berdasarkan metode pengumpulan data, analisa pieces untuk mengevaluasi kinerja system, dan metode rancangan menggunakanuml (unifield modeling language) yang meliputi usecase, activity, squence dan class diagram sebagai alat untuk memberikan gambaran rancangan yang berjalan maupun yang akan diciptakan. Lalu untuk proses pengolahan database menggunakan mysql, yang pada akhirnya akan menghasilkan sistem yang terintegrasi dengan baik, sehingga model yang dibuat diharapkan dapat melakukan perhitungan kinerja guru dan tenaga kependidikan dengan cepat, akurat, obyektif dan transparan.Hal ini bisa dilakukan karena proses perhitungan dilakukan secara komputerisasi, dan kategori penilaian meliputi sangat baik, baik, cukup dan kurang. Selain itu adanya dashboard dalam bentuk rekapitulasi dapat dijadikan dasar pengambilan keputusan.
\end{abstract}

Kata Kunci: penilaian kinerja, guru, tenaga kependidikan, pelayanan sekolah.

\begin{abstract}
The process of evaluating the performance of teachers and education personnel in several schools is still carried out manually, where the calculation of performance is only seen based on absenteeism and is still very subjective, this is quite time consuming in the calculation so that it is ineffective and inefficient besides the results are less accurate. To overcome the problems above, we need a computerized system so that it can solve the problem and speed up the process. Therefore, this study proposes the design of teacher and staff performance appraisal systems automatically based on data collection methods, pieces analysis to evaluate system performance, and design methods using uml (unifield modeling language) which includes usecase, activity, squence and class diagrams as a tool to provide an overview of the design that is running or will be created. Then for the database processing using mysql, which will ultimately produce a well-integrated system, so that the model created is expected to be able to calculate the performance of teachers and education personnel quickly, accurately, objectively and transparently. This can be done because the calculation process is computerized, and the assessment categories include very good, good, sufficient and less. In addition the existence of a dashboard in the form of recapitulation can be used as a basis for decision making.
\end{abstract}

Keywords: performance appraisal, teachers, education personnel, school services 


\section{PENDAHULUAN}

Segala aspek pendukung yang mendorong sekolah untuk melakukan langkah-langkah strategis agar tetap eksisdalam bidang pendidikan untuk maju dan berkembang, tidak terlepas dari kapasitas kinerja guru dan tenaga kependidikan [1].Tingkat persaingan kerja yang semakin besar mendorong guru dan tenaga kependidikan untuk lebih meningkatkan kinerjanya dan memberikan kinerja yang terbaik melalui penerapan penilaian kinerja.

Penilaian kinerja merupakan deskripsi sistematik, formal, dan evaluatif terhadap kualitas pekerjaan yang memiliki standar tertentu mengenai kelebihan serta kekurangan karyawan secara individu maupun kelompok, hal tersebut merupakan fungsi yang penting bagi personalia dan manajemen sumber daya manusia dalam perusahaan[2]. Ada beberapa fungsi dan kegunaan yang dapat diperoleh dari penilaian kinerja. Salah satu penggunaan penilaian kinerja yang paling umum adalah untuk pembuatan keputusan administratif yang berkaitan dengan promosi, pemberhentian, pemutusan hubungan kerja dan peningkatan upah berdasarkan atas jasa karyawan[3].

Sistem adalah suatu rangkaian yang terdiri dari dua atau lebih komponen yang saling berhubungan dan saling berinteraksi satu sama lain untuk mencapai tujuan dimana sistem biasanya terbagi dalam sub sistem yang lebih kecil yang mendukung sistem yang lebih besar[4]. Ketersediaan informasi yang cepat dan akurat serta didukung dengan penerapan sistem yang optimal menjadi kelebihan sendiri harus dimiliki setiap perusahaan. [5] Perancangan Sistem adalah suatu kegiatan membuat desain teknis berdasarkan kegiatan pada waktu proses analisis. Perancangan disini dimaksudkan suatu proses pemahaman dan peran suatu sistem informasi berbasis komputer. [6]Data adalah fakta dari hasil pengukuran atau pengamatan. Data dapat berupa huruf-huruf, angka, simbol-simbol khusus, atau gabungan darinya. [7]

\section{METODE PENELITIAN}

Metode penelitian merupakan suatu tata cara atau kegiatan pelaksanaan penelitian rangka untuk mengumpulkan informasi atau data serta melakukan investigasi terhadap data yang telah didapatkan tersebut. yang didasari oleh asumsi-asumsi dasar, pandangan-pandangan filosofis dan ideologis, pertanyaan dan isu-isu yang dihadapi. Suatu penelitian mempunyai rancangan penelitian tertentu. Rancangan ini menggambarkan prosedur atau langkah-langkah yang harus ditempuh, waktu penelitian, sumber data dan kondisi arti untuk apa data dikumpulkan dan dengan cara bagaimana data tersebut dihimpun dan diolah untuk dianalisa dalam pembuatan laporan.

\subsection{Metode Observasi (Observasi Research)}

Pada tahapan ini penulis melakukan pengamatan langsung dari objek penelitian untuk mendapatkan data dan informasi yang akurat dan lengkap dari berbagai pihak yang terkait dan berhubungan dengan tema penelitian yang berhasil penulis rumuskan.

\section{a. Metode Wawancara (Interview Research)}

Penulis melakukan wawancara dengan bagian terkaityang mengolah data guru dan tenaga kependidikan, penulis mendapatkan informasi berkaitan dengan penelitian penulis.

\section{b. $\quad$ Metode Studi Pustaka (Studi Literature)}

Selain melakukan observasi penulis juga melakukan data dengan cara studi pustaka, dalam metode ini penulis berusaha untuk melengkapi data-data yang diperoleh dengan membaca dan mempelajari dari buku-buku dan data-data yang relevan. Buku dan data tersebut digunakan penulis untuk membantu penganalisaan dan perancangan yang dilakukan.

\subsection{Metode Analisis Data}

Pada penelitian ini, metode analisa dilakukan dengan langkah-langkah melakukan pengamatan dan analisa terhadap sistem yangberjalan saat ini, serta menentukan UML (Unified Modeling Language) yang meliputi use case diagram, activity diagram, sequence diagram. 


\section{PEMBAHASAN}

Untuk dapat menggambarkan prosedur secara keseluruhan diperlukan bebrapa tahapan analisa sebagai bentuk pengumpulan informasi guna mendapatkan model yang sesuai dengan kebutuhan dan mampu memberikan solusi dengan cepat secara efektif dan efisien, mulai dari tahapan pengumpulan informasi dan kebutuhan, analisa dokumen, merancangan hubungan antar dokumen sampai dengan merancanga model diagram database dan model rancangan sistem. Beberapa tahapan yang dimaksud sampai dengan model ranangan yang diciptakan dapat dilihat pada gambar $1,2,3,4,5$.

\subsection{Use Case Diagram Prosedur Berjalan}

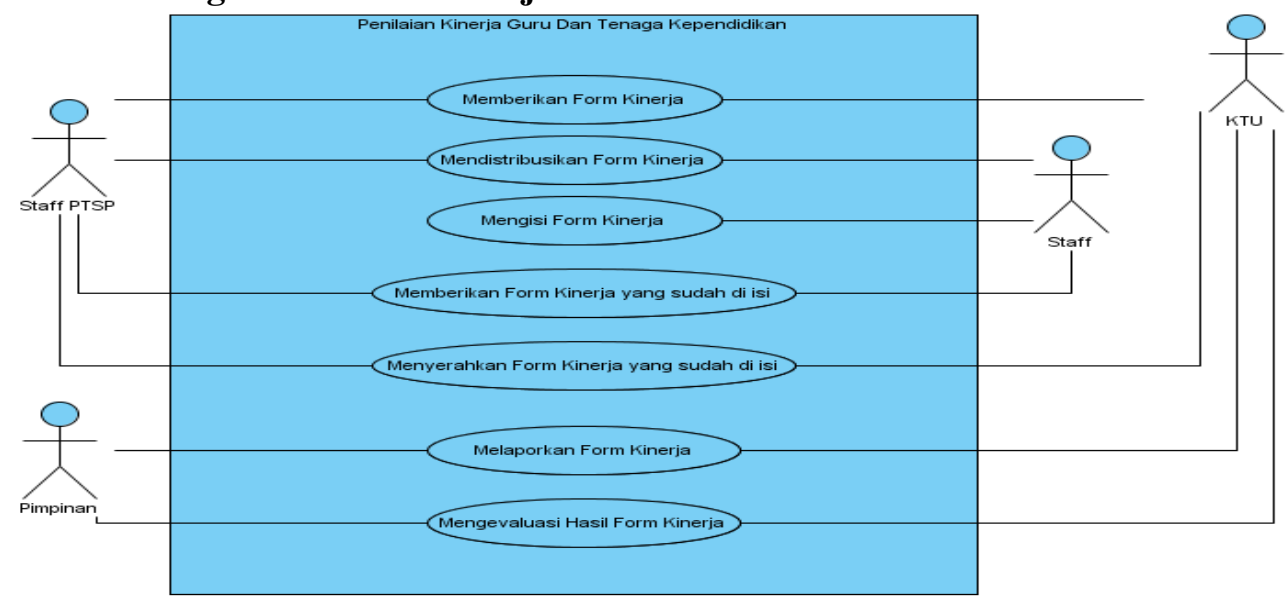

Gambar 1. Use Case Diagram

Berdasarkan gambar usecase diagram (gambar 1), sistem yang mencakup seluruh kegiatan penilian kinerja guru dan tanaga kependidikan. Terdapat 4 (empat) actor yang melakukan kegiatan yaitu KTU (Kepala Tata Usaha), Staff PTSP, Staff (Guru dan Tenaga Kependidikan), dan Pimpinan (Kepala Sekolah) yang berfungsi memberikan form kinerja, mendistribusikan form kinerja, mengisi form kinerja, memberikan form kinerja yang sudah di isi, menyerahkan form kinerja yang sudah di isi, melaporkan form kinerja dan mengevaluasi hasil form kinerja.

Terdapat juga 7 (tujuh) usecase yang merupakan proses yang terjadi pada sistem berjalan yaitu KTU memberikan form kinerja kepada Staff PTSP, Staff PTSP mendistribusikan form kinerja kepada Staff, Staff mengisi form kinerja, Staff memberikan form kinerja yang sudah di isi kepada Staff PTSP, Staff PTSP menyerahkan form kinerja yang sudah di isi kepada KTU,setelah itu KTU melaporkan form kinerja kepada Pimpinan, selanjutnya Pimpinan mengevaluasi hasil form kinerja.

\subsection{Activity Diagram Prosedur Berjalan}




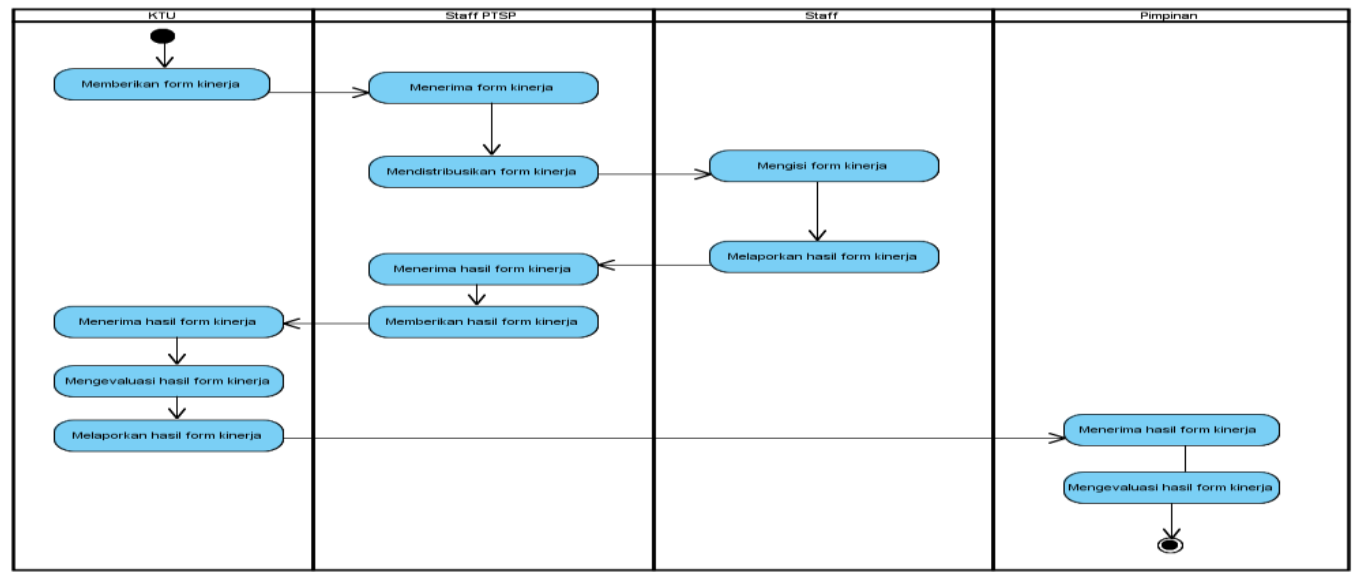

Gambar 2. Activity Diagram

Berdasarkan gambar activity diagram (gambar 2) yang berjalan saat ini sistem mencakup seluruh kegiatan guru dan tenaga kependidikan.Sistem ini melibatkan 4 (empat) Actor yaitu,KTU memberikan form kinerja kepada Staff PTSP, Staff PTSP menerima dan mendistribusikan form kinerja kepada Staff, Staff mengisi form kinerja dan melaporkan form kinerja yang sudah di isi kepada Staff PTSP, Staff PTSP menerima form kinerja dari Staff lalu menyerahkan form kinerja yang sudah di isi kepada KTU,setelah itu KTU melaporkan form kinerja kepada Pimpinan, selanjutnya Pimpinan mengevaluasi hasil form kinerja.

\subsection{Squence Diagram Prosedur Berjalan}

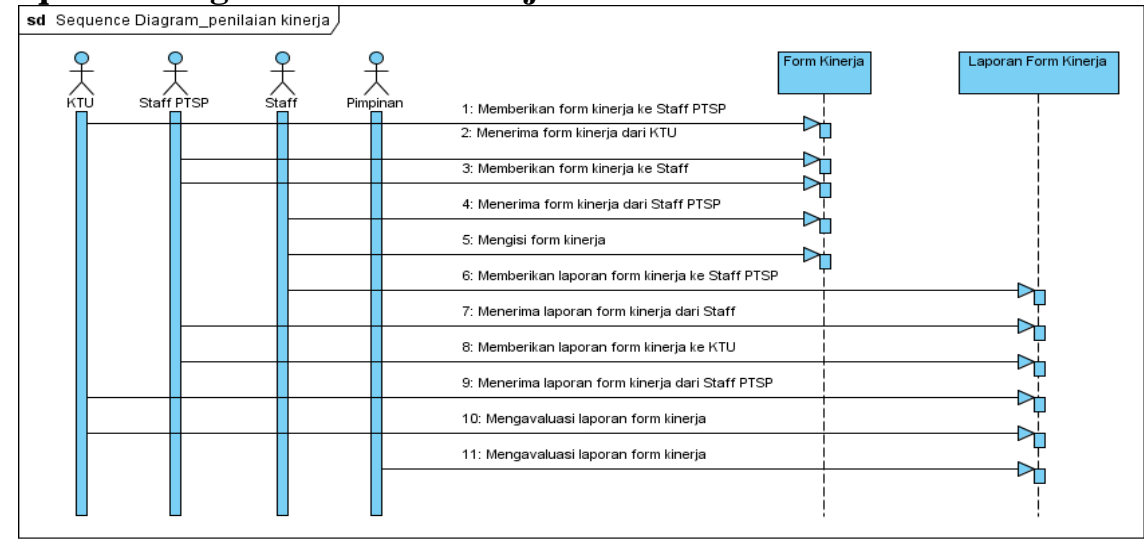

Gambar 3. Sequence Diagram

Berdasarkan gambar sequence diagram (gambar 3) yang berjalan saat ini terlihat 4(empat) actor yang melakukan kegiatan diantaranya: KTU, Staff PTSP, Staff, dan Pimpinan yang akan menyelesaikan 11 message spesifikasi dari komunikasi antar objek yang memuatinformasiinformasi tentang aktifitas yang terjadi, yaitu KTU memberikan form kinerja kepada Staff PTSP, Staff PTSP menerima dan mendistribusikan form kinerja kepada Staff, Staff mengisi form kinerja dan melaporkan form kinerja yang sudah di isi kepada Staff PTSP, Staff PTSP menerima form kinerja dari Staff lalu menyerahkan form kinerja yang sudah di isi kepada KTU,setelah itu KTU melaporkan form kinerja kepada Pimpinan, selanjutnya Pimpinan mengevaluasi hasil form kinerja.

Rancangan diatas (gambar 1, 2, 3) merupakan gambaran prosedur yang berjalan dimana pada tahapan ini melibatkan form kinerja. Dimana form kinerja diisi oleh Staff (Guru dan Tenaga Kependidikan)dan KTU bertugas memeriksa hasil laporan form kinerja yang telah diisi, setelah itu melaporkannya kepada Pimpinan (Kepala Sekolah). 


\subsection{Class Diagram}

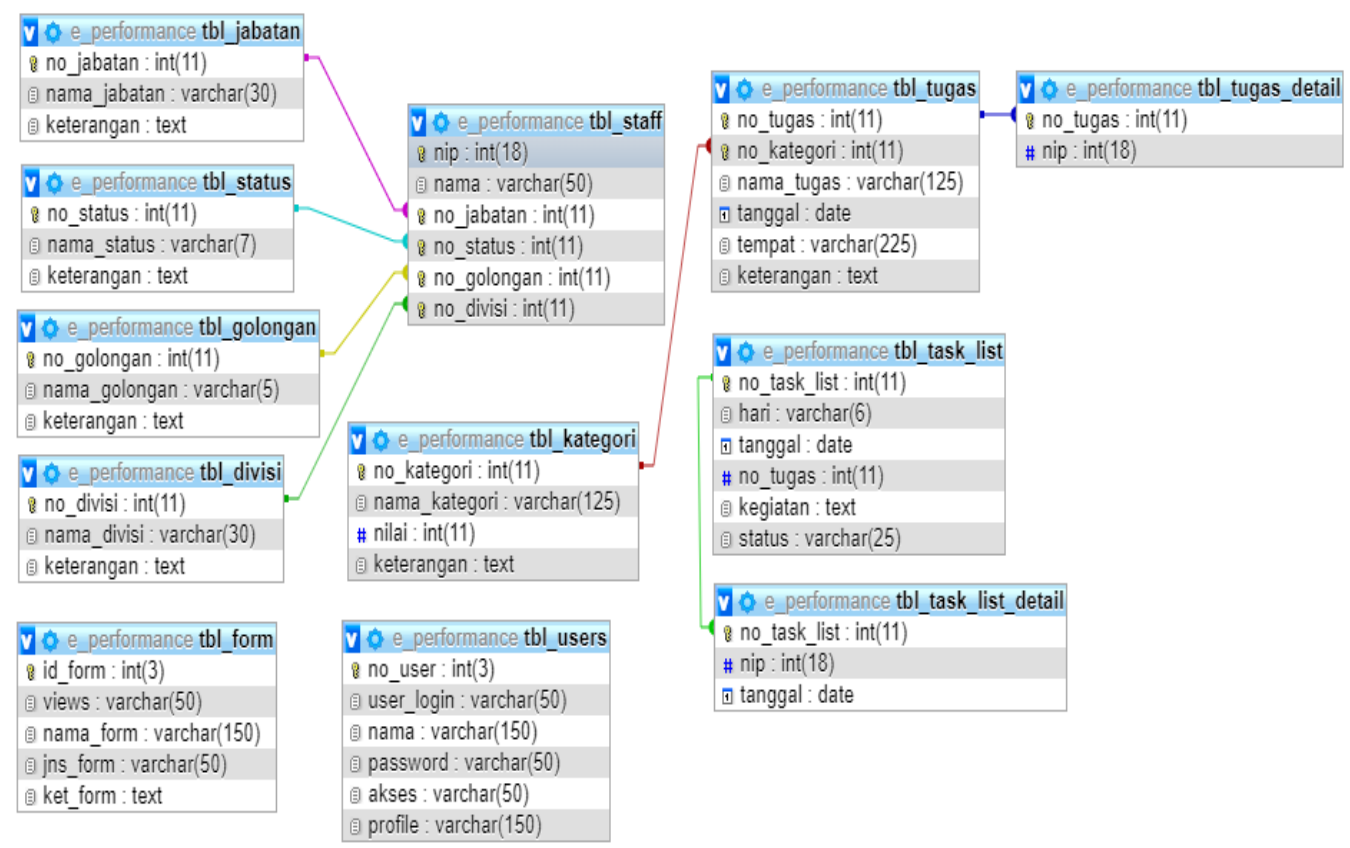

\section{Gambar 4. Class Diagram}

Berdasarkan gambar class diagram (gambar 4) yang berjalan saat ini sistem yang mencakup seluruh kegiatan pada sistem penilaian kinerja. Terdapat 12 (dua belas) class yaitu tbl_jabatan, tbl_status, tbl_golongan, tbl_divisi, tbl_staff, dan tbl_kategoriyang merupakan tabel master, tbl_tugas, tbl_task_list sebagai tabel transaksi,tbl_task_list_detail, dan tbl_tugas_detail sebagai tabel histori, juga terdapat tbl_users yang merupakan tabel akses untuk masuk ke dalam system, serta tbl_form menyimpan semua pengaturan.

Berdasarkan gambar class diagram (gambar 4) diatas dapat dilihat dengan jelas bahwa tingkat hubungantbl_jabatan dan tbl_staff yaitu one to many (1:M), tingkat hubungan tbl_status dan tbl_staff yaitu one to many $(1: \mathrm{M})$, ), tingkat tbl_golongan dan tbl_staffyaitu one to many (1:M), tingkat hubungan tbl_divisi dan tbl_staff yaitu one to many (1:M), tingkat tbl_kategori dan tbl_tugasyaitu one to many (1:M), tingkat tbl_tugas dan tbl_tugas_detail yaitu one to many (1:M). Sementara tabel staff berhubungan dengan 4(empat) tabel yaitu tbl_jabatan untuk mengikat jabatan staff, tbl_status untuk menentukan status PNS atau Honorer, tbl_golongan untuk mengikat golongan staff berdasarkan status, tbl_divisi untuk mengikat dibagian mana staff itu ditempatkan.

\subsection{Use Case Diagram Usulan}




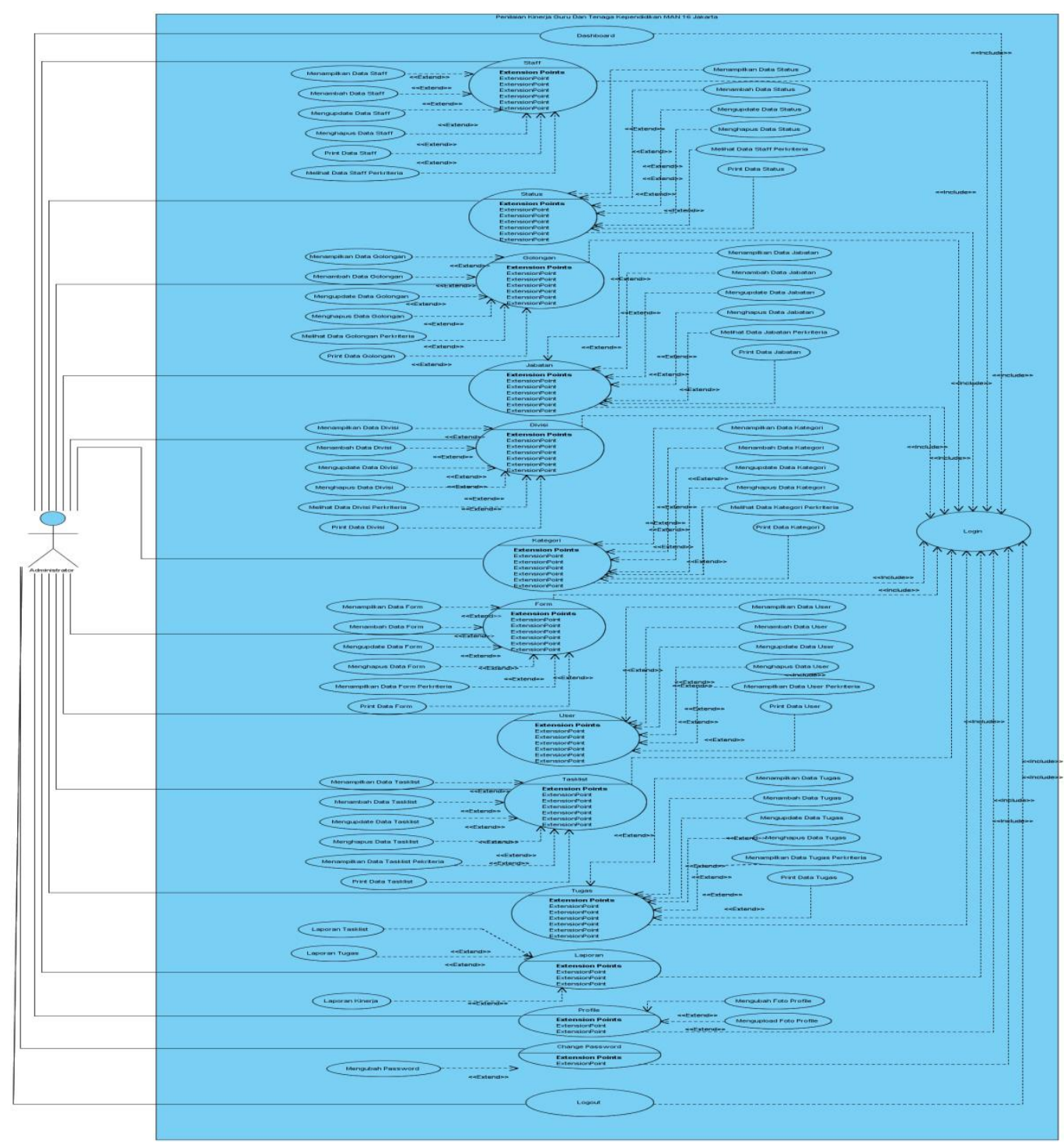

Gambar 5. Use Case Diagram Usulan

Berdasarkan gambar use case diagram usulan (gambar 5) terlihat jelas bahwa terdapat 16(lima belas) use case yang terdiri darilogin, dashboard, staff, status, golongan, jabatan, divisi, kategori, form, user, tasklist, tugas, laporan, profile, change password, dan logout. Dimana login dan logout berfungsi sebagai kontrol untuk memfilter siapa saja yang bisa mengakses sistem, dashboard berfungsi untuk menampilkan rekapitulasi penilaian kinerja dalam bentuk diagram, staff berfungsi untuk pengelolaan data staff, status berfungsi untuk pengelolaan data status, golongan berfungsi untuk pengelolaan data golongan, jabatan berfungsi untuk pengelolaan data jabatan, divisi berfungsi untuk pengelolaan data divisi, kategori berfungsi untuk pengelolaan data kategori, form berfungsi untuk pengelolaan data form, user berfungsi untuk pengelolaan data user, tasklist berfungsi untuk pengelolaan data tasklist, tugas berfungsi untuk pengelolaan data tugas, laporan berfungsi menampilkan laporan tasklist, laporan tugas, dan laporan kinerja, profile berfungsi untuk mengubah foto profile dan mengupload foto profile, change password berfungsi untuk mengubah password. 


\subsection{IMPLEMENTASI}

\subsubsection{Rancangan Basis Data}

Untuk dapat menggamarkan bentuk basis data secara utuh, peneliti penggunakan aplikasi microsoft access sebagai bentuk gambaran dasar, dan pada akhirnya bentuk rancangan basis data ini dapat disesuaikan menggunakan apa saja sesuai kebutuhan.

\section{a. Tabel Master: Divisi}

Primary Key : no_divisi

Foreign Key : : -

Structure Tabel $\quad: \quad$ \{no_divisi, nama_divisi,keterangan \}

\begin{tabular}{|c|c|c|c|c|c|c|c|c|}
\hline & \# & Name & Type & Collation & Attributes & Null & Default Comments & Extra \\
\hline$\square$ & 1 & no_divisi & $\operatorname{int}(11)$ & & & No & None & AUTO_INCREMENT \\
\hline$\square$ & 2 & nama_divisi & varchar(30) & latin1_swedish_ci & & Yes & None & \\
\hline$\square$ & 3 & keterangan & text & latin1_swedish_ci & & Yes & None & \\
\hline
\end{tabular}

Tabel 1. Struktur Divisi

b. Tabel Master: Golongan

Primary Key : no_golongan

Foreign Key : -

Structure Tabel : \{no_golongan, nama_golongan, no_telp, keterangan \}

\# Name Type Collation Attributes Null Default Comments Extra

$\begin{array}{llllll}\square & \text { no_golongan } & \text { int(11) } & \text { No None } & \text { AUTO_INCREMENT } \\ \square & 2 & \text { nama_golongan } & \operatorname{varchar}(5) & \text { latin1_swedish_ci } & \text { Yes None } \\ 3 & \text { keterangan } & \text { text } & \text { latin1_swedish_ci } & \text { Yes None }\end{array}$

c. Tabel Master: Jabatan

Tabel 2. Strutur Golongan

Primary Key : no_jabatan

Foreign Key : -

Structure Tabel $\quad: \quad\{$ no_ jabatan, nama_jabatan, keterangan $\}$

\begin{tabular}{|c|c|c|c|c|c|c|c|}
\hline & $\#$ & Name & Type & Attributes & Null & Default Comments & Extra \\
\hline$\square$ & 1 & no_jabatan & $\operatorname{int}(11)$ & & No & None & AUTO_INCREMENT \\
\hline$\square$ & 2 & nama_jabatan & $\operatorname{varchar}(30)$ & latin1_swedish_ci & Yes & None & \\
\hline$\square$ & 3 & keterangan & text & latin1_swedish_ci & Yes & None & \\
\hline
\end{tabular}

Tabel 3. Struktur Jabatan

d. Tabel Master: Kategori

Primary Key :no_kategori

Foreign Key : -

Structure Tabel $:\{$ no_kategori, nama_kategori, nilai, keterangan

$\begin{array}{llllll}\# & \text { Name } & \text { Type } & \text { Collation } & \text { Attributes } & \text { Null Default Comments Extra } \\ \square & 1 & \text { no_kategori } & \text { int(11) } & \text { No None } & \text { AUTO_NCREMENT } \\ \square & 2 & \text { nama_kategori } & \operatorname{varchar(125)} \text { latin1_swedish_ci } & \text { Yes None } \\ \square & 3 & \text { nilai } & \text { int(11) } & & \text { Yes None } \\ \square & 4 & \text { keterangan } & \text { text } & \text { latin1_swedish_ci } & \text { Yes None }\end{array}$

Tabel 4. Struktur Kategori

e. Tabel Master: Status

Primary Key :nip

Foreign Key : : -

Structure Tabel : \{nip, nama, no_jabatan, no_status, no_golongan \}

\begin{tabular}{lllll}
$\#$ & Name & Type & Collation & Attributes Null Default Comments Extra \\
\hline & nip & $\operatorname{int}(18)$ & No None & AUTO_INCREMENT \\
\hline & nama & $\operatorname{varchar}(50)$ & latin1_swedish_ci & No None \\
\hline & no_jabatan & $\operatorname{int}(11)$ & No None \\
\hline & no_status & $\operatorname{int}(11)$ & No None \\
\hline 5 & no_golongan $\operatorname{int}(11)$ & No None
\end{tabular}


f. Tabel Transaksi: Status

Tabel 5. Struktur Staff

Primary Key :no_status

Foreign Key :

Structure Tabel : \{ no_status, nama_status, keterangan \}

\begin{tabular}{|c|c|c|c|c|c|c|c|c|}
\hline & \# & Name & Type & Collation & Attributes & Null & Default Comments & Extra \\
\hline$\square$ & 1 & no_status & $\operatorname{int}(11)$ & & & No & None & AUTO_INCREMENT \\
\hline$\square$ & 2 & nama_status & $\operatorname{varchar}(7)$ & latin1_swedish_ci & & Yes & None & \\
\hline$\square$ & 3 & keterangan & text & latin1_swedish_ci & & Yes & None & \\
\hline
\end{tabular}

Tabel 6. Struktur Status

g. Tabel Transaksi: Tasklist

Primary Key : no_tasklist

Foreign Key :

Structure Tabel : $\quad$ no_tasklist, nip, tanggal, no_tugas, kegiatan, status, user_create

\begin{tabular}{|c|c|c|c|c|c|c|c|}
\hline & \# & Name & Type & Attributes & Null & Default Comments & Extra \\
\hline$\square$ & 1 & no_task_list & $\operatorname{int}(11)$ & & No & None & AUTO_INCREMENT \\
\hline$\square$ & 2 & nip & $\operatorname{varchar}(10)$ & latin1_swedish_ci & No & None & \\
\hline$\square$ & 3 & tanggal & date & & Yes & None & \\
\hline$\square$ & 4 & no_tugas & $\operatorname{int}(11)$ & & Yes & None & \\
\hline$\square$ & 5 & kegiatan & text & latin1_swedish_ci & Yes & None & \\
\hline$\square$ & 6 & status & varchar(25) & latin1_swedish_ci & Yes & None & \\
\hline$\square$ & 7 & user_create & varchar(10) & latin1_swedish_ci & No & None & \\
\hline
\end{tabular}

Tabel 7. Struktur Tasklist

h. Tabel Transaksi: Tugas

Primary Key : no_tugas

Foreign Key :

Structure Tabel : \{ no_tugas, no_kategori, nama_tugas, tanggal_tugas, tempat, keterangan\}

\begin{tabular}{|c|c|c|c|c|c|c|c|}
\hline & $\#$ & Name & Type & Collation & Null & Default Comments & Extra \\
\hline$\square$ & 1 & no_tugas & $\operatorname{int}(11)$ & & No & None & AUTO_INCREMENT \\
\hline$\square$ & 2 & no_kategori & $\operatorname{int}(11)$ & & Yes & None & \\
\hline$\square$ & 3 & nama_tugas & varchar(125) & latin1_swedish_ci & Yes & None & \\
\hline$\square$ & 4 & tanggal_tugas & date & & Yes & None & \\
\hline$\square$ & 5 & tempat & varchar(225) & latin1_swedish_ci & Yes & None & \\
\hline$\square$ & 6 & keterangan & text & latin1_swedish_ci & Yes & None & \\
\hline
\end{tabular}

Tabel 8. Struktur Tugas

\subsection{Grafik Monitoring Kinerja Guru dan Tanaga Kependidikan}

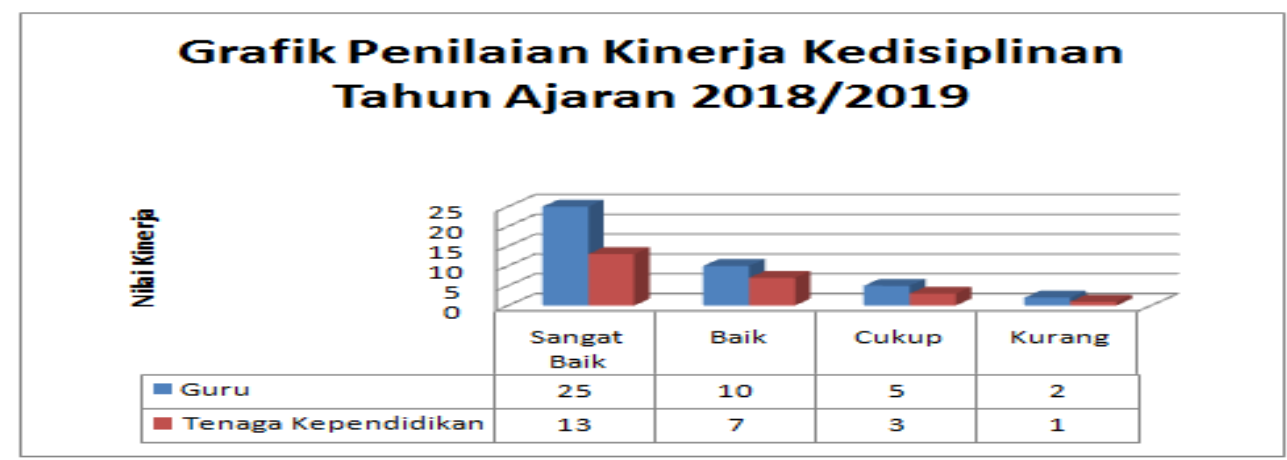

Gambar 6. Grafik Penilaian Kinerja

Grafik diatas (gambar 6) merupakan grafik penilaian kinerja kedisiplinan guru dan tenaga kependidikan tahun ajaran (2018/2019). Hal ini bisa membantu kepala madrasah untuk mengambil keputusan.Grafik diatas bisa diambil berdasarkan Datewarehouse, sebagaimana di definisikan "Doing Data Warehouse (DW) to your business or system is not only think about the trend only, but how to understand the DW knowledge itself and how to implement it" [8]. Dan bagaimana cara mengukurnya "Measures are a standard unit used to express the size, amount, or degree of something, qualities are often difficult to be measured as it needs to have 
some certain parameter or elements, and those parameters must be quantifiable and verifiable" [9].

\subsection{Diagram HIPO}

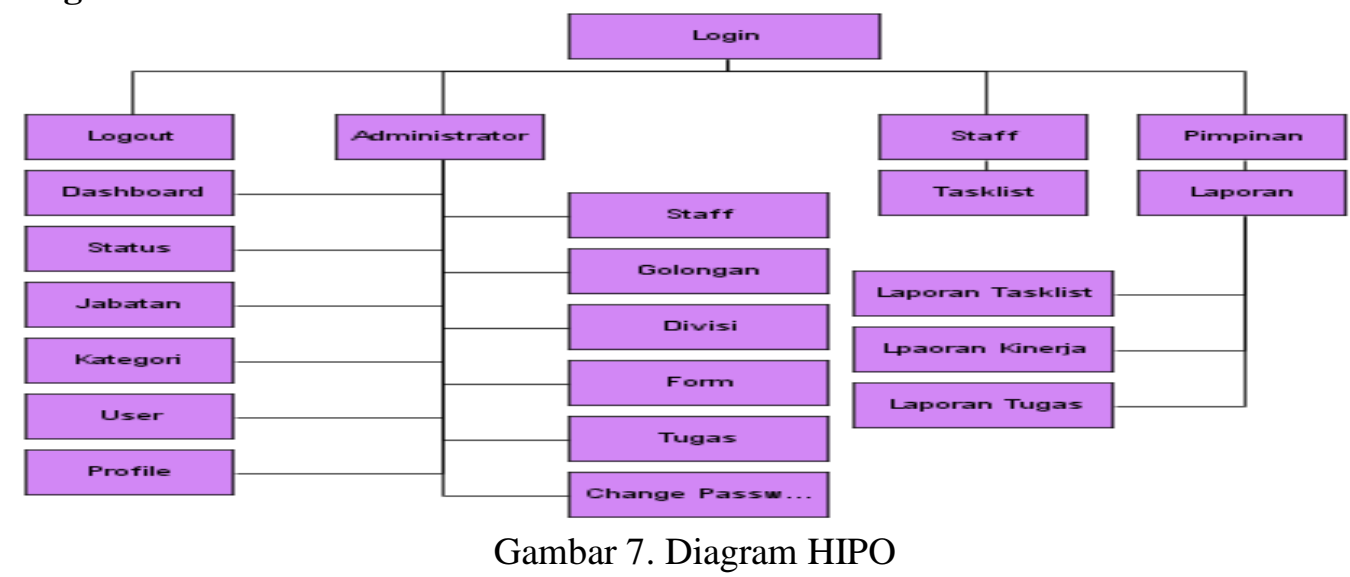

Untuk menggambarkan stuktur menu dari sistem yang dirancang dapat digambarkan dengan diagram HIPO (Hierarchy Input Process Output).Untuk menyediakan suatu struktur guna memahami fungsi-fungsi dari program.Terlihat dari diagram HIPO diatas (gambar 7) terdapat 1 (satu) fungsi utama yaitu login (diagram 0), menu login ini memiliki 3 hak akses yaitu Administrator (diagram 1), Staff (diagram 2), Pimpinan (diagram 3), dan menu Logout (diagram 4). Didalam hak akses administrator (diagram 1) terdapat 12 (dua belas) fungsi sub menu yaitu menu Dashboard (diagram 1.1), menu Staff (diagram 1.2), menu Status (diagram 1.3), menu Golongan (diagram 1.4), menu Jabatan (diagram 1.5), menuDivisi(diagram 1.6), menu Kategori (diagram 1.7), menu Form (diagram 1.8), menu User (diagram 1.9), menu Tugas (diagram 1.10), menu Profile (diagram 1.11), menu Change Password (diagram 1.12). Didalam hak akses Staff (diagram 2) terdapat 1 (satu) fungsi sub menu yaitu menu Tasklist (diagram 2.1). di dalam hak akses Pimpinan (diagram 3), terdapat 1 (satu) fungsi sub menu Laporan (3.1), di dalam fungsi sub menu Laporan terdapat 3 (tiga) sub menu yaitu Laporan Tasklist (3.1.1), Laporan Tugas (3.1.2), Laporan Kinerja (3.1.3).

\subsection{Rancangan Tampilan}

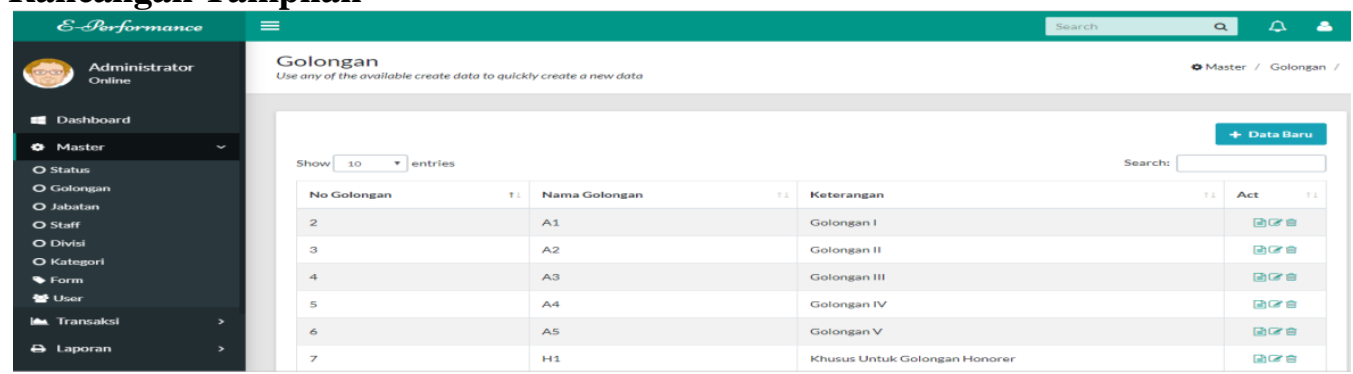

Gambar 8. Rancangan Layar Menu Golongan

Terlihat pada tampilan layar diatas (gambar 8) merupakan tampilan rancangan layar menu golongan. 


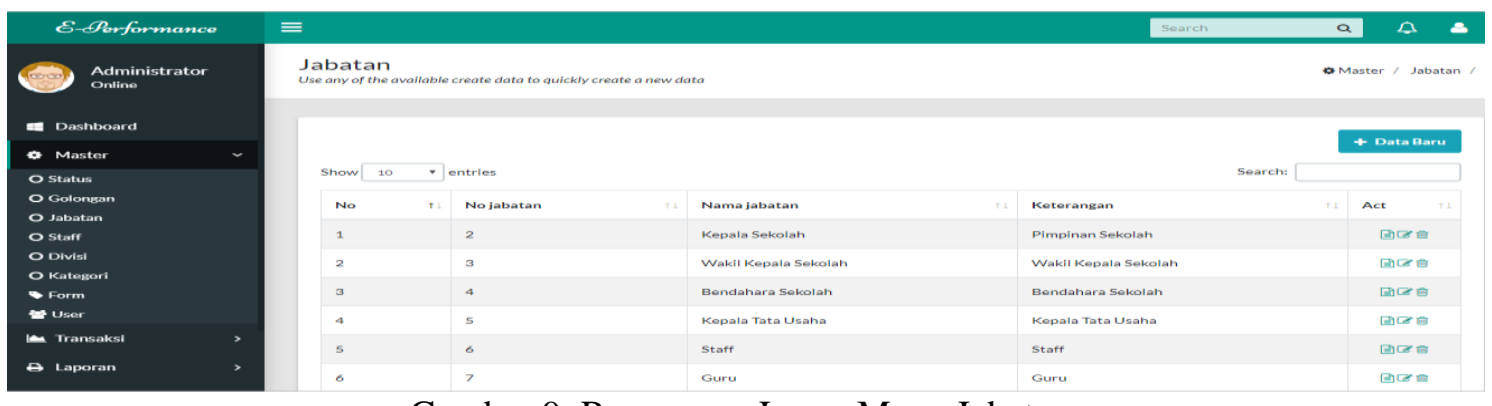

Gambar 9. Rancangan Layar Menu Jabatan

Terlihat pada tampilan layar diatas (gambar 8) merupakan tampilan rancangan layar menu golongan.

\subsection{Query Penciptaan Informasi}

\section{Query Function Menampilkan Data Kategori:}

function kategori_list()

$\{\quad \$ s q l="$ select $*$ from tbl_kategori"; $\$$ this->sql $=\$$ sql; $\$ \mathrm{i}=0$;

\$query=\$this->mysqli->query (\$sql) or die (\$this->mysqli->error());

while (\$result=\$query->fetch_assoc())

\{ \$this->no_kategori[\$i] $=$ \$result['no_kategori'];

\$this->nama_kategori[\$i]=\$result['nama_kategori'];

\$this->nilai[\$i] $=\$$ result['nilai'];

\$this->keterangan[\$i] $=$ \$result['keterangan'];

$\$ i++;\} ;$ return true; $\$$ this->mysqli->close ()$;\}$

\section{Query Function Merubah Data Kategori:}

function kategori_select()

$\{\quad \$ s q l="$ select $*$ from tbl_kategori where no_kategori='".\$this->no_kategori."'";

\$this->sql=\$sql;

$\$$ query=\$this->mysqli->query $(\$$ sql $)$ or die (\$this->mysqli->error () );

while (\$result=\$query->fetch_assoc())

\{ \$this->no_kategori $=\$$ result['no_kategori'];

\$this->nama_kategori=\$result['nama_kategori'];

$\$$ this->nilai=\$result['nilai']; \$this-> keterangan $=\$$ result['keterangan']; $\}$

return true; $\$$ this->mysqli->close ()$;\}$

\section{Query Function Menyimpan Data Kategori:}

function kategori_save()

$\{\quad$ \$sql="insert into tbl_kategori

Set; no_kategori="'.\$this->no_kategori."',

nama_kategori="'.\$this->nama_kategori."',nilai="'.\$this->nilai."',

keterangan="'.\$this->keterangan."' ";

\$query=\$this->mysqli->query $(\$$ sql) or die (\$this->mysqli->error () );

return true; $\$$ this->mysqli->close ()$;\}$

\section{KESIMPULAN}

Berdasarkan hasil analisa dan penelitian yang dilakukan, dapat disimpulkan bahwa proses penilaian kinerja guru dan tenaga kependidikan yang saat ini berjalan masih manual, dimana perhitungan kinerja hanya dilihat berdasarkan absensi dan masih sangat subyektif, hal ini cukup memakan waktu dalam perhitungan sehingga tidak efektif dan efisien selain itu hasil kurang akurat. Dengan model yang dibuat diharapkan perhitungan kinerja guru dan tenaga 
kependidikan dapat dilakukan denagn cepat, akurat, obyektif dan transparan karena proses perhitungan dilakukan secara komputerisasi untuk menentukan kategori penilaian yang meliputi sangat baik, baik, cukup dan kurang. Selain itu adanya dashboard dalam bentuk rekapitulasi dapat dijadikan dasar pengambilan keputusan.

\section{SARAN}

Untuk menanggulangi permasalahan dan mencapai hasil yang lebih baik, maka peneliti ingin memberikan saran yang sesuai dengan apa yang telah di teliti, adapaun saran-saran tersebut adalah sebagai berikut :

1. Perlu dilakukan pemeliharaan dan pengawasan dari pihak yang bertanggung jawab terhadap sistem agar tidak dirusak oleh hacker atau virus.

2. Memilih seorang administrator yang terlatih, jujur, dan bertanggung jawab, baik dalam penggunaan maupun pemeliharaan program aplikasi.

\section{DAFTAR PUSTAKA}

[1] Junaidi, J., Roji, A., \& Munawar, K. (2015). Konsep Otomatisasi Sistem Pembayaran SPP Online Untuk Mengurangi Tingkat Keterlambatan. Proceedings Konferensi Nasional Sistem dan Informatika (KNS\&I).

[2] Wijayanti, dkk. 2012 "Evaluasi dan Pengembangan Sistem Penilaian kinerja pada PT HKS".Jurnal Psikologi Undip Vol. 1 No. 2. Oktober 2012

[3] Taufik, dkk. 2014 PERANCANGAN APLIKASI SISTEM PENILAIAN KINERJA KARYAWAN DENGAN METODE MBO DAN BARS (STUDI KASUS PLTA MANINJAU).Jurnal Optimasi Sistem Industri Vol. 13 No. 2

[4] Junaidi, J., Effendy, M. Y., \& Hartono, H. (2015). REKAYASA MODEL APLIKASI SISTEM PRODUCT KNOWLADGE UNTUK MENDUKUNG PENGAMBILAN KEPUTUSAN DALAM MENENTUKAN KINERJA KARYAWAN. CERITA Journal, 1(1), 46-55.

[5] Martono, A., \& Junaidi, D. Y. IMULATION GAME BASED ON JARIMAGIC METHOD TO CALCULATE MORE QUICKLY FOR ELEMENTARY STUDENTS.

[6] Junaidi, J., Sutrisno, S., \& Janah, K. (2019). MODEL APLIKASI PURCHASING SYSTEM UNTUK MONITORING STOK DALAM MENGURANGI TINGKAT KERUGIAN. SENSI Journal, 5(1), 86-98.

[7] M. Subekti, Warnars Junaidi, H.L.H.S., Y. Heryadi, "The 3 steps of best data warehouse model design with leaning implementation for sales transaction in franchise restaurant", Cybernetics and Computational Intelligence (CyberneticsCom) 2017 IEEE International Conference on, 20-22 Nov 2017.

[8] Junaidi, J., Cholisoh, N., \& Hasanah, N. (2018). Rancang Bangun Sistem Manajemen Aset IT Untuk Pencatatan History Maintenance Sebagai Pendukung Keputusan. SENSI Journal, 4(2), 220-231.

[9] J. Junaidi, A. Julianto, N. Anwar, S. Safrizal, H.L.H.S. Warnars, K. Hashimoto, "Perfecting a Video Game with Game Metrics", Telkomnika, vol. 16, no. 3, pp. 13241331, June 2018 